\title{
Hubungan Status Gizi, Pemberian Asi Eksklusif dan Paparan Asap Rokok Terhadap Kejadian Ispa pada Balita di Puskesmas Sukaraya Kab. OKU
}

\author{
Fauziah Setiawati ${ }^{1 *}$, Erma Puspita Sari ${ }^{2}$, Siti Aisyah Hamid ${ }^{3}$, Hasbiah $^{4}$ \\ ${ }^{1}$ Program Studi Kebidanan Universitas Kader Bangsa Palembang \\ ${ }^{2,3,4}{ }^{4}$ Universitas Kader Bangsa, Jln HM Ryacudu No 887 Ulu Palembang Sumatera Selatan \\ *Correspondence e-mail: ermapuspitasari88@gmail.com
}

\begin{abstract}
Abstrak. Infeksi Saluran Pernapasan Akut (ISPA) merupakan penyebab utama morbididtas dan mortalitas balita baik di negara maju maupun berkembang dalam beberapa dekade terakhir. Hasil Riskesdas 2018, prevalensi ISPA pada balita di Indonesia 7,8 $\%$, dan Sumatera Selatan 8,6\%. Prevalensi ISPA di Kab. OKU tahun 2020 14,9\%, dan UPTD Puskesmas Sukaraya 19,9\%. Tujuan penelitian ini adalah untuk mengetahui hubungan status gizi, pemberian ASI eksklusif dan paparan asap rokok secara simultan dengan kejadian ISPA pada balitadi Puskesmas SukarayaKab. OKU Tahun 2021. Penelitian ini merupakan penelitian kuantitatif dengan metode survei analitik menggunakan pendekatan cross sectional. Sampel dalam penelitian ini di ambil secara Non Random Sampling dengan tehnik Accidental Sampling.Penelitian ini menggunakan data primer yang dikumpulkan dengan tehnik wawancara.Analisis data dilakukan secara univariat dan bivariat dengan uji statistik Chi-Square. Hasil analisis univariat: dari 46 sampel, $30(65,2 \%)$ menderita ISPA, $16(34,8 \%)$ gizi tidak baik, $21(45,7 \%)$ tidak ASI eksklusif dan $17(37 \%)$ terpapar asap rokok. Hasil analisis bivariat: ada hubungan bermakna antara status gizi ( $p$-value $0,008<\alpha 0,05)$, pemberian ASI eksklusif ( $p$ value $0,018<\alpha 0,05)$ dan paparan asap rokok $(p$-value $0,005<\alpha 0,05)$ secara simultan terhadap kejadian ISPA pada balita di Puskesmas Sukaraya Kab. OKU Tahun 2021. Adapun saran kepada pimpinan dan tenaga kesehatan UPTD Puskesmas Sukaraya untuk meningkatkan kerjasama lintas program dan lintas sektor dalam penanganan ISPA, dan diharapkan masyarakat berperan serta menurunkan angka kejadian ISPA pada balita dengan memberikan asupan bergizi, ASI eksklusif dan berperilaku hidup bersih dan sehat.
\end{abstract}

Kata kunci : ASI eksklusif; Infeksi Saluran Pernapasan Akut (ISPA); paparan asap rokok ; status gizi

\begin{abstract}
Acute Respiratory Tract Infection (ARI) is the main cause of morbidity and mortality of children under five in both developed and developing countries. The results of Riskesdas 2018, the prevalence of ARI among children under five in Indonesia is 7.8\% and South Sumatra is 8.6\%. The prevalence of ARI in Kab.OKU in 2020 14.9\% and UPTD Sukaraya Health Center 19.9\%. The purpose of this study was to determine the relationship between nutritional status, exclusive breastfeeding and exposure to cigarette smoke simultaneously with the incidence of ARI in children under five at PuskesmasSukarayaKab. OKU 2021. This research is a quantitative study with an analytical survey method using a cross sectional approach. The sample in this study was taken in a non-random with accidental sampling technique. This study uses primary data collected through interview techniques. Data analysis was carried out univariate and bivariate with Chi-Square statistical test. The results of univariate analysis: from 46 samples, 30 (65.2\%) suffered from ARI, 16 (34.8\%) were not well nourished, 21 (45.7\%) were not exclusively breastfed and 17 (37\%) were exposed to cigarette smoke. The results of bivariate analysis: there is a significant relationship between nutritional status ( $p$-value 0.008), exclusive breastfeeding ( $p$-value 0.018) and exposure to cigarette smoke (p-value 0.005) simultaneously on the incidence of ARI among children under five at PuskesmasSukarayaKab. OKU 2021. As for suggestions to the leadership and health workers of UPTD PuskesmasSukaraya to increase cross-program and cross-sectoral collaboration in handling ARI, and it is hoped that the community will participate in reducing the incidence of ARI in toddlers by providing nutritious intake, exclusive breastfeeding and clean and healthy living behavior
\end{abstract}

Keywords: Exclusive Breastfeeding; Acute Respiratory Infection; Nutritional Status

\section{PENDAHULUAN}

Infeksi Saluran Pernapasan Akut (ISPA) merupakan penyebab utama angka kesakitan (morbiditas) dan angka kematian (mortalitas) balita baik di negara maju maupun berkembang dalam beberapa dekade terakhir. Menurut Rudan et al, terdapat 156 juta kasus baru ISPA di dunia pertahun dimana 151 juta kasus $(96,7 \%)$ terjadi di negara berkembang (Kemenkes RI, 2016). Berdasarkan data World Health Organization (WHO) tahun 2016, diperkirakan angka kematian balita akibat ISPA di benua Amerika, Afrika dan Asia sebesar 15-20\% pertahun dan pneumonia merupakan penyebab utama kematian balita di dunia (Sabri, dkk, 2019).
Hasil Riset Kesehatan Dasar (Riskesdas) 2018 menunjukkan prevalensi (angka kejadian) ISPA di Indonesia mengalami penurunan dibandingkan hasil Riskesdas 2013 yaitu dari 25\% menjadi 9,3\% dan prevalensi ISPA pada balita sebesar $7,8 \%$. Sementara itu prevalensi pneumonia pada balita juga mengalami penurunan dari $18,5 \%$ menjadi $4,8 \%$ (Kemenkes RI, 2018). Namun demikian proporsi kematian balita akibat pneumonia masih tinggi. Pada tahun 2019 angka kematian akibat pneumonia pada balita sebesar $0,12 \%$. Menurut data Ditjen Kesehatan Masyarakat Kemenkes RI tahun 2020, pneumonia manjadi penyebab utama kematian post-neonatal (29 hari-11 bulan) pada tahun 
2019 yaitu 979 kematian (15,9\%) dan menjadi penyebab kematian terbesar kedua setelah diare pada anak balita (12-59 bulan) yaitu 277 kematian $(9,5 \%)$ (Kemenkes RI, 2020).

Prevalensi ISPA pada balita di Sumatera Selatan berdasarkan hasil Riskesdas 2018 sebesar 8,6\%. Sementara itu, menurut data dari Dinkes Propinsi Sumsel tahun 2021, prevalensi ISPA pada balita cenderung tetap dari tahun 2019 sampai 2020 dimana pada tahun 2019 sebesar 154.573 kasus $(17,68 \%)$ dan pada tahun 2020 sebesar 154.546 kasus $(17,67 \%)$. Adapun cakupan penemuan Pneumonia balita mengalami penurunan dari tahun 2016 ke 2018 yaitu dari 44,86\% menjadi 39,24\%, dan tahun 2019 kembali turun menjadi $33.8 \%$. Namun demikian, pada tahun 2018 pneumonia masih menjadi penyebab kematian utama pada bayi dan penyebab kedua kematian anak balita (Dinkes Provinsi Sumsel, 2018).Tahun 2019 pneumonia menjadi penyebab kematian kedua setelah diare pada bayi (10 kasus) dan anak balita (3 kasus) (Kemenkes RI, 2020).

Prevalensi ISPA pada balita di Kabupaten OKU cenderung menurun dari tahun 2018 sampai 2020 dimana pada tahun 2018 sebesar 10.915 kasus $(29,4 \%)$, pada tahun 2019 sebesar 8.930 kasus $(24,8 \%)$ dan pada tahun 2020 sebesar 5.371 kasus (14,9\%). Namun demikian ISPA masih menempati posisi tertinggi 10 penyakit terbanyak di Kabupaten OKU (Dinkes Kab.OKU, 2021).

Infeksi Saluran Pernapasan Akut (ISPA) adalah infeksi akut yang menyerang salah satu bagian/ lebih dari saluran napas mulai dari hidung sampai alveoli termasuk adneksanya (sinus, rongga telinga tengah dan pleura).Pneumonia adalah infeksi akut yang menyerang jaringan paru-paru (alveoli). Pneumonia Balita ditandai dengan gejala batuk dan atau kesukaran bernapas seperti napas cepat, tarikan dinding dada bagian bawah kedalam (TDDK), atau gambaran radiologi foto thorax /dada yang menunjukkan infiltrate paru akut (Kemenkes RI, 2016).

Jika ISPA tidak ditangani, maka akan menyebabkan pneumonia dan kematian pada balita. Beberapa faktor resiko terjadinya ISPA antara lain kurangnya pemberian ASI eksklusif, gizi buruk, polusi udara dalam ruangan (indoor air pollution) seperti kebiasaan merokok orangtua/ anggota keluarga, berat badan bayi lahir rendah (BBLR), kepadatan penduduk serta imunisasi campak (Kemenkes RI, 2016).

Status gizi adalah gambaran seseorang sebagai akibat dari asupan gizi sehari-hari.Seseorang yang mempunyai status gizi baik tidak mudah terkena penyakit, baik penyakit infeksi maupun penyakit degeneratif (Harjatmo dkk, 2017).

Gizi buruk merupakan faktor predisposisi terjadinya ISPA pada balita.Asupan makanan yang tidak teratur dan nutrisi yang tidak seimbang menyebabkan balita mengalami kekurangan gizi sehingga rentan terhadap penyakit infeksi termasuk ISPA dan TBC.

Berdasarkan hasil penelitian Yanti dan Sari (2018) yang berjudul Analisis Faktor yang Berhubungan dengan Kejadian ISPA pada Anak Balita Usia 1-5 tahun di Wilayah Kerja Puskesmas Sukaraja Nuban Kabupaten Lampung Timur di dapati dari 43 balita dengan status gizi baik ada $27,9 \%$ yang menderita ISPA, dan dari 90 balita dengan status gizi kurang ada $80 \%$ yang menderita ISPA. Dari hasil uji analisis Chi Square didapatkan $\mathrm{p}$ value $0,001<\alpha 0,05$ yang berarti ada hubungan status gizi dengan kejadian ISPA pada Balita.

Pemberian ASI Eksklusif berhubungan erat dengan kejadian ISPA pada balita.Hal ini karena ASI mengandung kolostrum yang banyak mengandung antibody terhadap infeksi pernapasan dan sel darah putih, serta vitamin A yang dapat memberi perlindungan terhadap infeksi dan alergi.

Berdasarkan penelitian Kartini (2019) dengan judul Faktor-faktor yang berhubungan dengan kejadian ISPA pada anak balita di Posyandu Melati Kelurahan Cibinong, didapati dari 71 balita yang tidak mendapat ASI eksklusif ada $88,7 \%$ yang menderita ISPA, dan dari 28 balita yang mendapat ASI eksklusif ada $28,6 \%$ yang menderita ISPA. Hasil Uji analisis Chi Squaremendapatkan p value $0,000<\alpha 0,05$ yang artinya ada hubungan riwayat ASI eksklusif dengan kejadian ISPA pada anak balita.

Asap rokok dapat mengganggu saluran pernapasan bahkan meningkatkan resiko penyakit infeksi pernapasan termasuk ISPA terutama pada kelompok umur balita yang memiliki daya tahan tubuh masih lemah sehingga bila ada paparan asap, maka balita lebih cepat terganggu sistem pernapasannya.

Berdasarkan penelitian Amin (2020) dengan judul Analisis Faktor Resiko Kejadian ISPA pada Balita di Wilayah Puskesmas Talang Pangeran Kabupaten Ogan Ilir, didapati dari 21 balita yang anggota keluarganya memiliki kebiasaan merokok ada 57,1\% yang menderita ISPA dan dari 19 balita yang anggota keluarganya tidak memiliki kebiasaan merokok ada $21,1 \%$ yang menderita ISPA. Hasil Uji analisis Chi Squaremendapatkan p value $0,045<\alpha 0,05$ yang artinya ada hubungan perilaku merokok anggota keluarga dengan kejadian ISPA pada anak balita.

UPTD Puskesmas Sukaraya merupakan Puskesmas yang terletak di daerah perkotaan dengan kunjungan ISPA balita terbanyak dari Puskesmas kota lainnya. Berdasarkan data dari program P2 ISPA Puskesmas Sukaraya, angka kejadian ISPA pada balita tahun 2018 sebesar 751 kasus (24,4\%), tahun 2019 sebesar 972 kasus $(31,2 \%)$ dan pada tahun 2020 sebesar 628 kasus (19,9\%). Sedangkan angka kejadian ISPA balita pada semester pertama 2021 sebesar 308 kasus $(9,5 \%)$ (Data Primer UPTD Puskesmas Sukaraya Kabupaten OKU, 2021). 
Fauziah Setiawati et al., Hubungan Status Gizi, Pemberian Asi Eksklusif dan Paparan Asap Rokok Terhadap Kejadian Ispa pada Balita di Puskesmas Sukaraya Kab. OKU

Penelitian ini bertujuan untuk mengetahui hubungan status gizi, pemberian ASI Eksklusif dan paparan asaparokok dengan kejadian ISPA pada balita.

\section{METODE}

Penelitian ini adalah penelitian kuantitatif dengan menggunakan survey analitik dengan desain penelitian cross sectional, dimana peneliti melakukan observasi atau pengukuran variabel pada saat tertentu yang artinya tiap subjek hanya di observasi satu kali dan pengukuran variabel subjek dilakukan pada saat penelitian tersebut (Sucipto, 2020).

Popuasi pada penelitian ini adalah Populasi penelitian ini adalah seluruh balita sakit (usia 0-59 bulan) yang berkunjung ke UPTD Puskesmas Sukaraya bulan Juli - Agustus 2021. Tehnik pegambilan sampel menggunakan teknik Accidental Sampling yaitu pengambilan sampel berdasarkan individu yang dijumpai di tempat dan pada saat penelitian dilakukan. Sampel penelitian ini adalah seluruh balita sakit (usia 059 bulan) yang berkunjung ke UPTD Puskesmas Sukaraya pada saat penelitian dilakukan.

Penelitian ini telah memperoleh surat keterangan lolos kaji etik dari Komite Etik Penelitian Kesehatan Fakultas Kesehatan Universitas Kader Bangsa Palembang dengan No:172/UKB.FKES/TU.KEPK/2021 pengambilan data dilakukan selama empat minggu pada bulan Juli-Agustus tahun 2021 dengan menggunakan lembar kuesioner.

\section{HASIL DAN PEMBAHASAN Analisis Univariat}

Hasil analisis univariat Kejadian ISPA pada Balita tergambar pada tabel 1 .

Tabel 1. Distribusi Frekuensi dan Persentase Responden Berdasarkan Kejadian ISPA Pada Balita Puskesmas Sukaraya Kabupaten OKU

\begin{tabular}{lcc}
\hline Kejadian ISPA & Frekuensi (f) & Persentase (\%) \\
\hline Ya & 30 & 65,2 \\
Tidak & 16 & 34,8 \\
Total & $\mathbf{4 6}$ & $\mathbf{1 0 0}$
\end{tabular}

Sumber data: hasil penelitian

Berdasarkan Tabel 1 diketahui bahwa dari 46 responden, jumlah balita yang menderita ISPA sebanyak 30 orang $(65,2 \%)$ dan balita yang tidak menderita ISPA yaitu sebanyak 16 orang $(34,8 \%)$.

Hasil analisis univariat faktor status gizi tergambar pada tabel 2 .
Tabel 2. Distribusi Frekuensi dan Persentase Responden Berdasarkan Status Gizi Pada Balita Puskesmas Sukaraya Kabupaten OKU

\begin{tabular}{lcc}
\hline \multicolumn{1}{c}{ Status Gizi } & Frekuensi (f) & Persentase $(\%)$ \\
\hline Tidak Baik & 16 & 34,8 \\
Baik & 30 & 65,2 \\
Total & $\mathbf{4 6}$ & $\mathbf{1 0 0}$ \\
& & \\
\hline
\end{tabular}

Sumber data: hasil penelitian

Berdasarkan Tabel 2 diketahui bahwa diketahui bahwa dari 46 responden, jumlah balita dengan status gizi tidak baik ada 16 orang $(34,8 \%)$ dan 30 orang $(65,2 \%)$ balita dengan status gizi baik.

Hasil analisis univariat faktor pemberian ASI Eksklusif tergambar pada tabel 3.

Tabel 3. Distribusi Frekuensi dan Persentase Responden Berdasarkan Pemberian Asi Eksklusif Pada Balita Puskesmas Sukaraya Kabupaten OKU

\begin{tabular}{lcc}
\hline Pemberian Asi Eksklusif & Frekuensi (f) & Persentase (\%) \\
\hline Tidak & 21 & 45,7 \\
Ya & 25 & 54,3 \\
Total & $\mathbf{4 6}$ & $\mathbf{1 0 0}$
\end{tabular}

Sumber data: hasil penelitian

Berdasarkan Tabel 3 diketahui bahwa dari 46 responden, jumlah balita yang tidak mendapat ASI eksklusif sebanyak 21 orang $(45,7 \%)$ dan 25 orang $(54,3 \%)$ balita yang mendapat ASI eksklusif.

Hasil analisis univariat faktor Paparan Asap Rokok tergambar pada tabel 4.

Tabel 4. Distribusi Frekuensi dan Persentase Responden Berdasarkan Paparan Asap Rokok Pada Balita Puskesmas Sukaraya Kabupaten OKU

\begin{tabular}{lcc}
\hline Paparan Asap Rokok & Frekuensi (f) & Persentase (\%) \\
\hline Ya & 17 & 37,0 \\
Tidak & 29 & 63,0 \\
Total & $\mathbf{4 6}$ & $\mathbf{1 0 0}$
\end{tabular}

Sumber data: hasil penelitian

Berdasarkan Tabel 4 diketahui bahwa dari 46 responden, jumlah balita yang terpapar asap rokok sebanyak 17 orang (37\%) dan 29 orang (63\%) balita yang tidak terpapar asap rokok.

\section{Analisis Bivariat}

Analisis ini dilakukan untuk mengetahui hubungan antara variabel dependen (kejadian ISPA) dengan variabel independen (status gizi, pemberian ASI Eksklusif dan paparan asap rokok)

Hasil analisis bivariat hubungan status gizi, pemberian ASI Eksklusif dan paparan asap rokok dengan kejadian ISPA pada Balita dapat dilihat pada tabel 5 . 
Fauziah Setiawati et al., Hubungan Status Gizi, Pemberian Asi Eksklusif dan Paparan Asap Rokok Terhadap Kejadian Ispa pada Balita di Puskesmas Sukaraya Kab. OKU

Tabel 5. Hubungan Variabel Independen dan Variabel Dependen

\begin{tabular}{|c|c|c|c|c|c|c|c|c|c|}
\hline \multirow{3}{*}{ No } & \multirow{3}{*}{ Variabel Independen } & \multicolumn{4}{|c|}{ Kejadian ISPA } & \multirow{2}{*}{\multicolumn{2}{|c|}{ Total }} & \multirow{3}{*}{$\underset{\text { Value }}{P}$} & \multirow{3}{*}{$\begin{array}{c}\text { Odd } \\
\text { Ratio } \\
95 \% \text { CI }\end{array}$} \\
\hline & & \multicolumn{2}{|c|}{ Ya } & \multicolumn{2}{|c|}{ Tidak } & & & & \\
\hline & & $\mathbf{n}$ & $\%$ & $\mathbf{n}$ & $\%$ & $\mathbf{N}$ & $\%$ & & \\
\hline \multirow[t]{3}{*}{1} & Status Gizi & & & & & & & & \\
\hline & 1. Tidak Baik & 15 & 93,8 & 1 & 6,3 & 16 & 100 & 0,008 & 15.000 \\
\hline & 2. Baik & 15 & 50,0 & 15 & 50,0 & 30 & 100 & & \\
\hline \multirow[t]{4}{*}{2} & Pemberian ASI & & & & & & & & \\
\hline & Eksklusif & 18 & 85,7 & 3 & 14,3 & 21 & 100 & 0018 & 6500 \\
\hline & 1. Tidak & & & & & & & 0,018 & 0.500 \\
\hline & 2. $\mathrm{Ya}$ & 12 & 48,0 & 13 & 52,0 & 25 & 100 & & \\
\hline \multirow[t]{3}{*}{3} & Paparan Asap Rokok & & & & & & & & \\
\hline & 1. $\mathrm{Ya}$ & 16 & 94,1 & 1 & 5,9 & 17 & 100 & 0,005 & 17.143 \\
\hline & 2. Tidak & 14 & 48,3 & 15 & 51,7 & 29 & 100 & & \\
\hline
\end{tabular}

Sumber data: hasil penelitian

Berdasarkan tabel 5 hasil analisis hubungan status gizi dengan Kejadian ISPA pada Balita diperoleh bahwa dari 16 balita dengan status gizi tidak baik yang menderita ISPA sebanyak 15 orang $(93,8 \%)$, sedangkan dari 30 balita dengan status gizi baik yang menderita ISPA sebanyak 15 orang $(50,0 \%)$. Hasil uji statistik diperoleh nilai $p$ value $=0,008 \leq \alpha=0,05$ maka dapat disimpulkan bahwa ada hubungan yang signifikan status gizi dengan Kejadian ISPA pada Balita Puskesmas Sukaraya Kab OKU tahun 2021. Hasil analisis diperoleh nilai OR : 15.000 , yang artinya balita dengan status gizi tidak baik berpeluang 15.000 kali menderita ISPA dari pada balita yang berstatus gizi baik.

Hasil Penelitian ini sejalan dengan penelitian Penelitian Sitepu (2018) juga mendapati ada hubungan status gizi dengan kejadian ISPA pada anak balita dimana dari 14 anak balita dengan status gizi tidak baik ada $64,3 \%$ yang menderita ISPA, dan dari 78 anak balita dengan status gizi baik ada 34,6\% yang menderita ISPA. Dari hasil uji analisis Chi Square didapatkan p value $0,036<\alpha 0,05$ yang berarti ada hubungan status gizi dengan kejadian ISPA pada anak balita. Hasil analisis juga memperoleh Rasio Prevalensi $(\mathrm{RP})=1,857$ yang berarti anak balita yang berstatus gizi tidak baik beresiko 1,857 kali mengalami ISPA dibandingkan anak yang berstatus gizi baik

Menururt Harjatmo dkk (2017), seseorang yang mempunyai status gizi baik tidak mudah terkena penyakit, baik penyakit infeksi maupun penyakit degeneratif.

Gizi buruk merupakan faktor predisposisi terjadinya ISPA pada balita.Asupan makanan yang tidak teratur dan nutrisi yang tidak seimbang menyebabkan balita mengalami kekurangan gizi sehingga rentan terhadap penyakit infeksi termasuk ISPA dan TBC (Yanti dan Sari, 2018).

Hasil penelitian di Puskesmas Sukaraya menunjukkan proporsi balita yang berstatus gizi tidak baik lebih banyak menderita ISPA daripada balita yang berstatus gizi baik. Peneliti berasumsi hal ini disebabkan masih rendahnya pengetahuan orangtua balita tentang ISPA, pola pemberian nutrisi yang tidak tepat dan kesadaran berperilaku hidup sehat yang masih kurang.

Hasil analisis hubungan pemberian ASI Eksklusif dengan Kejadian ISPA pada Balita diperoleh bahwa dari 21 balita yang tidak mendapat ASI eksklusif sebanyak 18 orang $(85,7 \%)$ menderita ISPA, sedangkan dari 25 balita yang mendapat ASI eksklusif sebanyak 12 orang $(48,0 \%)$ menderita ISPA. Hasil uji statistik chi square diperoleh nilai $p$ value $=0,018 \leq \alpha=0,05$, maka dapat disimpulkan bahwa ada hubungan yang signifikan pemberian ASI Eksklusif dengan Kejadian ISPA pada Balita. Hasil analisis diperoleh nilai OR : 6.500 artinya balita yang tidak mendapat ASI ekslusif berpeluang 6.500 kali menderita ISPA dibandingkan balita yang mendapat ASI eksklusif.

Hasil penelitian sejalan dengan penelitian Kartini (2019) yang mendapati dari 71 balita yang tidak mendapat ASI eksklusif ada $88,7 \%$ yang menderita ISPA dan dari 28 balita yang mendapat ASI eksklusif ada $28,6 \%$ yang menderita ISPA. Hasil Uji analisis Chi Squaremendapatkan $\mathrm{p}$ value $0,000<\alpha 0,05$ yang artinya ada hubungan riwayat ASI eksklusif dengan kejadian ISPA pada anak balita. Balita dengan riwayat pemberian ASI tidak eksklusif berpeluang 0,051 kali lebih besar terkena ISPA dibandingkan balita yang mendapat ASI eksklusif.

Berdasarkan teori, salah satu manfaat ASI bagi bayi adalah mengandung antibodi mekanisme pembentuk antibodi pada bayi. Jika ibu mendapat infeksi, maka tubuh ibu akan membentuk antibodi yang akan disalurkan kepada bayinya dengan bantuan jaringan limfosit. Dalam ASI juga terdapat antibodi terhadap bakteri E.Coli, Salmonella Typhii, Shigella dan antibodi terhadap virus seperti Rota Virus, polio serta campak (Susanto, 2021).

Pemberian ASI Eksklusif berhubungan erat dengan kejadian ISPA pada balita.Hal ini karena ASI mengandung kolostrum yang banyak mengandung antibodi terhadap infeksi pernapasan dan sel darah putih, 
Fauziah Setiawati et al., Hubungan Status Gizi, Pemberian Asi Eksklusif dan Paparan Asap Rokok Terhadap Kejadian Ispa pada Balita di Puskesmas Sukaraya Kab. OKU

serta vitamin A yang dapat memberi perlindungan terhadap infeksi dan alergi (Sabri dkk, 2019).

Hasil penelitian menunjukkan proporsi balita yang tidak mendapat ASI eksklusif lebih banyak daripada balita yang mendapat ASI eksklusif. Menurut peneliti hal ini dikarenakan kurangnya pengetahuan ibu tentang pentingnya pemberian ASI eksklusif. Alasan responden tidak memberikan ASI eksklusif karena ASI-nya kurang cukup, puting susu yang pendek, dan ibu yang bekerja sehingga ibu dan atau keluarga memberikan susu formula atau makanan lain seperti buah dan bubur sebelum balita berumur 6 bulan.

Hasil analisis hubungan paparan asap rokok dengan Kejadian ISPA pada Balita diperoleh bahwa dari 17 balita yang terpapar asap rokok, 16 orang $(94,1 \%)$ menderita ISPA dan dari 29 balita yang tidak terpapar asap rokok, 14 orang $(48,3 \%)$ menderita ISPA.

Hasil uji statistik chi square diperoleh nilai $p$ value $=0,005 \leq \alpha=0,05$, Hal ini menunjukkan bahwa ada hubungan bermakna antara paparan asap rokok dengan kejadian ISPA pada balita di Puskesmas Sukaraya Kab. OKU Tahun 2021. Sementara itu nilai OR yang diperoleh 17.143 artinya balita yang terpapar asaprokok berpeluang 17.143 kali menderita ISPA daripada balita yang tidak terpapar asap rokok.

Hasil penelitian ini sejalan dengan penelitian Amin dkk (2020) yang mendapati dari 21 balita yang anggota keluarganya memiliki kebiasaan merokok ada $57,1 \%$ yang menderita ISPA dan dari 19 balita yang anggota keluarganya tidak memiliki kebiasaan merokok ada $21,1 \%$ yang menderita ISPA. Hasil Uji analisis $C h i$ Squaremendapatkan p value $0,045<\alpha 0,05$ yang artinya ada hubungan kebiasaan merokok anggota keluarga dengan kejadian ISPA pada balita. Dari hasil analisa juga diperoleh Odd Ratio $(\mathrm{OR})=5$, artinya balita yang anggota keluarganya memiliki kebiasaan merokok berpeluang 5 kali menderita ISPA dibandingkan balita yang anggota keluarganya tidak memiliki kebiasaan merokok.

Paparan Asap Rokok dapat mengganggu saluran pernapasan bahkan meningkatkan resiko penyakit infeksi pernapasan termasuk ISPA terutama pada kelompok umur balita yang memiliki daya tahan tubuh masih lemah sehingga bila ada paparan asap, maka balita lebih cepat terganggu sistem pernapasannya (Yanti dan Sari, 2018).

Hasil penelitian menunjukkan proporsi balita yang terpapar asap rokok lebih banyak daripada balita yang tidak terpapar asap rokok. Menurut peneliti, kebiasaan merokok anggota keluarga berdampak buruk bagi kesehatan anggota keluarga lain terutama balita. Apalagi jika merokok di dalam rumah atau di dekat balita sangat beresiko menyebabkan balita terpapar asap rokok (menjadi perokok pasif) sehingga mudah terkena ISPA dikarenakan sistem kekebalan tubuh balita yang tidak sama seperti orang dewasa. Selain itu kebiasaan merokok juga mengindikasikan kurangnya kesadaran orangtua tua atau keluarga tentang pentingnya perilaku hidup sehat (PHBS).

\section{SIMPULAN}

Hasil analisis menunjukkan bahwa sttaus gizi (p.value 0,008), pemberian ASI Eksklusif (p.value 0,018 ) dan paparan asap rokok (p.value 0,005) memiliki hubungan signifikan dengan Kejadian ISPA pada Balita di Puskesmas Sukaraya. Hasil analisis diperoleh nilai OR : 15.000 , yang artinya balita dengan status gizi tidak baik berpeluang 15.000 kali menderita ISPA dari pada balita yang berstatus gizi baik, faktor pemberian ASI Eksklusif diperoleh nilai OR : 6.500 artinya balita yang tidak mendapat ASI ekslusif berpeluang 6.500 kali menderita ISPA dibandingkan balita yang mendapat ASI eksklusif, dan faktor paparan asap rokok diperoleh nilai OR yang diperoleh 17.143 artinya balita yang terpapar asaprokok berpeluang 17.143 kali menderita ISPA daripada balita yang tidak terpapar asap rokok.

\section{DAFTAR PUSTAKA}

Amin, Muhammad, dkk. 2020. Analisis Faktor Resiko Kejadian ISPA pada Balita. Babul Ilmi_Jurnal Ilmiah Kesehatan 12(2): Hal169-180.

Badan Litbangkes Kementrian Kesehatan Republik Indonesia. 2018. Laporan Nasional Riset Kesehatan Dasar (Riskesdas) Tahun 2018. Jakarta.

Dinas Kesehatan Propinsi Sumatera Selatan. 2021. Data Sekunder Angka Kejadian ISPA pada Balita di Provinsi Sumatera Selatan Tahun 2018-2020. Palembang.

Dinas Kesehatan Propinsi Sumatera Selatan, 2018. Rencana Kerja Dinas Kesehatan Proinsi Sumatera Selatan Tahun 2019. Palembang.

Dinas Kesehatan Kabupaten Ogan Komering Ulu. 2021. Data Sekunder Angka Kejadian ISPA pada Balita di Kabupaten Ogan Komering Ulu Tahun 20182021. Baturaja.

Harjatmo,T.P dkk. 2017. Bahan Ajar Gizi Penilaian Status Gizi. Pusat Pendidikan Sumber Daya Manusia Kesehatan Kemenkes RI. Jakarta.

Kartini F.D dan Andriati R.H. 2019. Faktor-Faktor yang Berhubungan Dengan Kejadian ISPA Pada Anak Balita di Posyandu Melati Kelurahan Cibinong. Jurnal Persada Husada Indonesia 6 (23): 42-49. Https://garuda.ristekbrin.go.id/documents/detail.1 $\underline{627756}$.

Kementrian Kesehatan Republik Indonesia. 2020. Profil Kesehatan Indonesia Tahun 2019. Jakarta: Kementrian Kesehatan RI.

Kementrian Kesehatan Republik Indonesia, 2018. Pedoman Proses Asuhan Gizi Puskesmas. Jakarta: Kementrian Kesehatan RI.

Kementrian Kesehatan Republik Indonesia, 2016. Revisi Buku Pedoman Pencegahan dan Pengendalian 
Fauziah Setiawati et al., Hubungan Status Gizi, Pemberian Asi Eksklusif dan Paparan Asap Rokok Terhadap Kejadian Ispa pada Balita di Puskesmas Sukaraya Kab. OKU

Infeksi Saluran Pernafasan Akut (ISPA). Jakarta: Kementrian Kesehatan RI.

Sabri, Rahman dkk. 2019. Faktor-faktor yang Mempengaruhi Tingginya Penyakit ISPA pada Balita di Puskesmas Deleng Pokhkisen Kabupaten Aceh Tenggara. Contagion Journal: Scientific Periodical of Public Health and Coastal Health 1 (2): Hal 69-82. http://jurnal.uinsu.ac.id/index.php/contagion

Sitepu, Riama Saradifa. 2018. Hubungan Status Pemberian ASI Eksklusif, Status Imunisasi Campak dan Status Gizi dengan Kejadian ISPA pada Anak Balita di Desa Sikap dan Desa Tanjung Barus. Skripsi Fakultas Kesehatan Masyarakat Universitas Sumatera Utara, Medan.

Profil UPTD Puskesmas Sukaraya Kab. OKU. 2021. Laporan Bulanan ISPA tahun 2018- 2021. Baturaja.

Sucipto, Cecep Dani. 2020. Metodologi Penelitian Kesehatan. Gosyen Publishing. Yogyakarta.

Susanto, Andina Vita. 2021. Asuhan Kebidanan Nifas dan Menyusui Teori Dalam Praktik Kebidanan Profesional. Pustaka Baru Press. Yogyakarta.

Yanti, DE dan Sari, Nurhalina. 2018. Analisis Faktor yang Berhubungan dengan Kejadian Infeksi Saluran Pernapasan Akut (ISPA) pada Anak Balita Usia 1-5 Tahun di Wilayah Kerja Puskesmas Sukaraja Kabupaten Lampung Timur. Jurnal Dunia Kesmas Vol 7. Nomor 4.Oktober 2018: Hal. 169-177 